\title{
EFEKTIVITAS PELAKSANAAN PERAN KELOMPOK SIAGA BENCANA KELURAHAN OLO DALAM UPAYA MITIGASI BENCANA GEMPA BUMI DAN TSUNAMI DI KAWASAN PANTAI PADANG
}

\author{
Chece Syahyanti $^{1(a)}$, Aldri Frinaldi ${ }^{2(b)}$ \\ ${ }^{1}$ Jurusan Ilmu Administrasi Negara, Universitas Negeri Padang \\ ${ }^{2}$ Jurusan Ilmu Administrasi Negara, Universitas Negeri Padang \\ a)checesyahyanti98@gmail.com, ${ }^{b}$ alfrinaldi@gmail.com
}

\begin{abstract}
The State of Indonesia is one of the countries prone to disasters, including the City of Padang. Thousands or even hundreds of thousands of people have become victims of natural disasters in Indonesia, including the earthquake and tsunami. Based on data from the Padang City Statistics Agency that the District in the City of Padang consists of 11 districts with a total of 104 villages. However, data from the Padang City Disaster Management Plan (RPB) the level of disasters in the kelurahan varies such as areas located in coastal areas, automatically the level of disaster risk that occurs is also high, one of which is Olo Kelurahan, then to undertake earthquake disaster mitigation efforts earth and tsunami formed the Disaster Preparedness Group. This study aims to determine the effectiveness of the implementation of the role of the Olo Village Disaster Preparedness Group in efforts to mitigate earthquakes and tsunamis in the Padang Beach region. This type of research is descriptive using qualitative methods. The results showed that the implementation of the role of the Olo Village Disaster Preparedness Group in efforts to mitigate the earthquake and tsunami in the Padang Beach area could be said to be ineffective. The problems encountered include: lack of education and training received, lack of funds / budget, inadequate facilities and infrastructure, lack of meetings conducted, lack of member activity, and lack of socialization given. This type of research is descriptive using qualitative methods. The results showed that the implementation of the role of the Olo Village Disaster Preparedness Group in efforts to mitigate the earthquake and tsunami in the Padang Beach area could be said to be ineffective. The problems encountered include: lack of education and training received, lack of funds / budget, inadequate facilities and infrastructure, lack of meetings conducted, lack of member activity, and lack of socialization given. This type of research is descriptive using qualitative methods. The results showed that the implementation of the role of the Olo Village Disaster Preparedness Group in efforts to mitigate the earthquake and tsunami in the Padang Beach area could be said to be ineffective. The problems encountered include: lack of education and training received, lack of funds / budget, inadequate facilities and infrastructure, lack of meetings conducted, lack of member activity, and lack of socialization given.
\end{abstract}

Keywords : Effectiveness, Disaster Mitigation, Implementation of the role of Disaster Preparedness Group

Corresponding author. Email.checesyahyanti98@gmail.com,alfrinaldi@gmail.com

How to cite this article. Syahyanti, C \& Frinaldi, A. (2020). Efektivitas Pelaksanaan Peran Kelompok Siaga Bencana Kelurahan Olo dalam Upaya Mitigasi Bencana Gempa Bumi dan Tsunami di Kawasan Pantai Padang. Jurnal Mahasiwa Ilmu Administrasi Publik (JMIAP) Jurusan Ilmu Administrasi Negara Fakultas Ilmu Sosial Universitas Negeri Padang, Volume 2 (2), Hal. 44-53.

http://jmiap.ppj.unp.ac.id

ISSN : 2684-818X (Online), ISSN : 2338-7378 (Print)

Copyright $\bigcirc 2020$. Published by Pusat Kajian-Pemberdayaan dan Pelayanan Masyarakat (PK-P2M) FIS UNP Padang 


\section{PENDAHULUAN}

Mitigasi bencana yaitu suatu kegiatan kebencanaan yang dilakukan oleh semua lapisan masyarakat, bukan hanya tanggung jawab Pemerintah semata dan dilakukan sebelum bencana itu terjadi (pra bencana). Kegiatan mitigasi bencana dilakukan bertujuan untuk mengurangi dampak buruk yang disebabkan oleh benana yang suatu waktu dapat terjadi.

Menurut Undang-Undang Republik Indonesia Nomor 24 Tahun 2007 tentang Penanggulangan Bencana, mitigasi adalah suatu upaya yang dilakukan untuk mengurangi risiko bencana, baik melalui pembangunan fisik maupun penyadaran dan peningkatan kemampuan manusia dalam menghadapi ancaman yang terjadi akibat terjadinya bencana. Puluhan bahkan ratusan ribu manusia terkena dampak bencana alam contohnya seperti gempa bumi, tsunami dan sebagainya. Penyebab Indonesia sering dilanda bencana karena berkaitan dengan letak geologi dan tektonik Negara Indonesia yang membentuk jalur gempa dan jalur gunung api dengan ribuan pusat gempa dan ratusan gunung api yang selalu menjadi penyebab bencana alam seperti: gempa, tsunami dan gunung meletus (Harjono dan Priyono dalam Humaedi, dkk 2013:28).

Bencana merupakan persoalan public administration dan public policy (Pramusinto, 2009). Persoalan yang berhubungan dengan terjadinya bencana termasuk ke dalam salah satu agenda public policy karena Wilayah Negara Kesatuan Republik Indonesia merupakan salah satu Negara yang sering ditimpa berbagai macam bencana alam. Salah satunya adalah bencana gempa bumi yang terjadi di Kota Padang pada tanggal 30 September 2009 yang meluluhlantahkan Kota Padang. Kota Padang termasuk dalam wilayah ring of fire atau lingkaran cincin api dunia, pada daerah ini rawan akan terjadinya pergerakan lempeng yang menimbulkan bencana gempa bumi hingga tsunami. Melihat kondisi geografis Kota Padang yang demikian, Pemerintah Kota Padang perlu melakukan upaya mitigasi bencana yang diarahakan kepada masyarakat. Upaya mitigasi bencana yang dilakukan guna mengurangi resiko bencana dan meminimalisir kerugian harta benda. Setelah terjadi gempa bumi tersebut tidak serta merta membuat Kota Padang aman dari bencana gempa bumi dan tsunami.

Dari data Indeks Rawan Bencana Tahun 2013 BNBP menyebutkan bahwa Kota Padang termasuk dalam salah satu daerah yang termasuk ke dalam daerah dengan tingkat bahaya bencana yang paling tinggi dibanding daerah Sumatera Barat lainnya (BNBP, 2013). Dari sekian banyak bencana yang terjadi, bencana yang paling mengancam kehidupan masyarakat dan lingkungannya adalah bencana gempa bumi dan tsunami. Terkait dengan letak Kota Padang berada di zona subduksi yaitu antara lempeng Indo-Australia dan Lempeng Eurasia. Fenomena tersebut menyebabkan Kota Padang menjadi daerah yang seringkali mengalami bencana gempa bumi. Sebagai kota yang rentan terhadap bencana gempa dan tsunami, Kota Padang memerlukan metode manajemen bencana yang efektif yang bertujuan agar masyarakat mengetahui benca gempa bumi yang bepotensi tsunami seperti menerapkan sistem peringatan dini tsunami (Frinaldi, 2018).

Berdasarkan hal tersebut maka dalam melakukan upaya mitigasi bencana gempa bumi dan tsunami dari Pemeritah Daerah Kota Padang membentuk suatu kelompok sosial yang ingin bekerja secara sukarela untuk masyarakat yang berada disekitarnya agar ikut berpartisipasi membantu Pemerintah Daerah dalam melakukan kegiatan kebencanaan dalam hal ini upaya mitigasi bencana yang kemungkinan terjadi di tengah masyarakat Kota Padang. Dijelaskan pada Undang-Undang Nomor 24 tahun 2007 tentang Penanggulangan Bencana yang bahwa Pemerintah dan Pemerintah Daerah adalah penanggung jawab penyelenggaraan kegiatan penanggulangan bencana. Namun pada pasal 27, diungkapkan bahwa setiap orang mempunyai kewajiban dalam 
melaksanakan kegiatan penanggulangan bencana.

Di tahap prabencana salah satu kegiatan yang dilakukan yaitu mitigasi bencana diantaranya upaya mitigasi bencana gempa bumi dan tsunami, dalam membantu tugas Pemerintah untuk melakukan upaya mitigasi bencana maka dibentuklah Kelompok Siaga Bencana (KSB) yang terdiri dari 11 Kelompok Siaga Bencana di Kecamatan Kota Padang dan 104 Kelompok Siaga Bencana di Kelurahan yang tersebar diberbagai wilayah di Kota Padang. Kelompok Siaga Bencana tersebut dibentuk oleh BPBD Kota Padang. Selanjutnya Kelompok Siaga Bencana yang berada di kelurahan merupakan perpanjangan tangan dari BPBD Kota Padang dalam melakukan upaya mitigasi bencana. Salah satu Kelompok Siaga Bencana yang ada di Kecamatan Padang Barat adalah Kelompok Siaga Bencana Kelurahan Olo yang berdiri pada tahun 2011 berdasarkan SK Lurah Olo Kecamatan Padang Barat Nomor 08/Tahun2020 tentang Pembentukan/Pembinaan Organisasi Penanggulangan Bencana Kelompok Siaga Bencana Tingkat Kelurahan Olo Kecamatan Padang Barat.

Peran Kelompok Siaga Bencana Kelurahan Olo sendiri salah satunya yaitu melakukan upaya mitigasi bencana gempa bumi dan tsunami bagi masyarakat, karena berkaitan dengan lokasi rumah mereka yang berada di sekitar kawasan pesisir pantai. Dalam melakukan peran sebagai relawan sosial tentu tidak selalu maksimal karena mereka memiliki pekerjaan utama disamping mereka menjadi relawan sosial bagi masyarakat.

Jumlah anggota Kelompok Siaga Bencana Kelurahan Olo ada sebanyak 13 orang, yang pada umumnya mempunyai pengetahuan yang minim dalam hal mitigasi bencana di Kelurahan Olo sediri. Selain itu, kendala lain yang di hadapi oleh Kelompok Siaga Bencana Kelurahan Olo dalah dari segi dana/anggaran, mereka tidak mendapatkan dana/anggaran yang menunjang kegiatan mereka dalam melakukan upaya mitigasi bencana gempa bumi dan tsunami baik itu dari BPBD ataupun dari Pemerintah Daerah. Oleh sebab itu, kegiatan mitigasi bencana dilakukan tidak rutin dan hanya memanfaatkan situasi saja. Selanjutnya, jika ditinjau dari segi sarana dan prasarana yang dimiliiki oleh Kelompok Siaga Bencana Kelurahan Olo juga sangat minim dan tidak difasilitasi oleh BPBD maupun Pemerintah Daerah. Disisi lain kurangnya keaktifan anggota Kelompok Siaga Bencana Kelurahan Olo mengakibatkan sosialisasi yang diterima oleh masyarakat juga sangat minim dan ada sebagian masyarakat yang belum mendapatkan sosialisasi terkait mitigasi bencana gempa bumi dan tsunami ini.

\section{TINJAUAN PUSTAKA \\ Efektivitas}

Dalam bahasa Inggris, efektivitas berasal dari kata effective yang memiliki makna berhasil. Hal ini juga dapat dikatakan bahwa, segala sesuatu yang dilakukan akan berhasil sesuai dengan yang diharapkan. The Liang Gie dalam Abdul Halim (2004:60) menjelaskan bahwa efektivitas yaitu suatu kondisi yang terjadi berdasarkan apa yang diinginkan. Hal ini berhubungan dengan suatu perbuatan yang dilaksanakan dan memiliki tujuan dan maksud tertentu. Oleh sebab itu perbuatan yang dilakukan itu dapat dikatakan efektif apabila tujuan yang telah ditentukan sebelumnya terlaksana dengan baik.

Menurut Steers (1985:46) yang menjelaskan bahwa efektivitas merupakan sejauh mana oganisasi dapat melakukan semua tugas pokoknya dalam mencapai tujuan telah ditentukan sebelumnya. Penilaian umum yang memiliki banyak kriteria tunggal akan menghasilkan penilaian yang umum. Berbeda dengan teori Etzioni dalam Muhyadi (1989:277) yang menjelaskan bahwa efektivitas dinilai sebagai kemampuan yang dimiliki oleh suatu organisasi dalam mencari sumber dan kemudian dapat memanfaatkannya dengan 
baik dalam memperoleh tujuan yang telah ditentukan sebelumnya.

Georgopolous dan Tannembaun dalam Mughron., dkk (2016:):3) menyatakan bahwa "Efektivitas di lihat dari segi pencapaian tujuan, keberhasilan dalamsuatu organisasi seharusnya dapat melaksanakan bukan hanya tujuan maupun sassaran dari organisasi tetapi juga harus memperhatikan mekanisme dalam mencapai suatu sasaran organisasi".

Gibson dalam Ahmad Subekti (2013:248) efektivitas merupakan kegiatan menilai yang diciptakan terkait keberhasilan organisasi maupun kelompok bahkan individu. Semakin sesuai keberhasilanm mereka dengan keberhasilan yang diharapkan, penilaiannya semakin efektif.

Jadi, dapat dipahami bahwa efektivitas merupakan tingkat pencapaian sasara, tujuan atau target suatu organisasi dalam melaksanakan seluruh tugas pokoknya. Adapun pengukuran efektivitas juga bisa dilakukan dalam dua kurun waktu yakni dalam waktu jangka pendek maupun jangka panjang sesuai dengan kesepakatan yang telah dibuat sebelumnya.

\section{Kelompok Siaga Bencana}

Kelompok siaga bencana atau yang biasa disebut KSB adalah relawan sosial yang diberi wewenang oleh BPBD dalam melakukan upaya mitigasi bencana dalam upaya mengurangi resiko bencana yang terjadi di wilayahnya sendiri. Terbentuknya KSB dikelurahan-kelurahan untuk melakukan pemantauan dimana saja kelurahan yang masyarakatnya tertimpa bencana.

Dalam melaksanakan perannya, Kelompok Siaga Bencana akan turun ke masyarakat untuk melakukan pendataan. Dapat dikatakan peranan Kelompok Siaga Bencana di Kelurahan sendiri yaitu lebih mendata, dan melaporkan ke BPBD apa yang terjadi di kelurahannya. Seperti ada musibah banjir, longsor, gempa bumi dan musibah lainnya, nanti Kelompok Siaga
Bencana di setiap kelurahan itu yang mendata dan melaporkan ke BPBD.

Jadi, dapat diketahui bahwa Kelompok Siaga Bencana adalah suatu kelompok sosial masyarakat yang dibentuk secara sukarela oleh Pemerintah Daerah untuk membantu dalam melakukan kegiatan yang berhubungan dengan kebencanaan.

\section{Manajemen Bencana}

Shaluf dalam Kusumasari (2014:19) mendefinisikan bahwa manajemen bencana disebut sebagai istilah yang kolektif dan meliputi seluruh bidang kegiatan perencanaan (planning) dalam menanggapi ketika terjadinya bencana, termasuk berbagai kegiatan yang dilakukan ketika prabencana maupun kegiatan yang dilakukan pasca bencana.

Manajemen bencana mecakup rencana yang dibuat, struktur yang ada, serta pengaturan yang dibuat dengan melibatkan seluruh lapisan baik pemerintah, sukarelawan, masyarakat, dan pihak swasta yang dilakukan melalui koordinasi untuk menanggapi dan menyediakan kebutuhan ketika terjadinya bencana. Maka dari itu, manejemen bencana meliputi kegiatan perencanaan (planning), pengorganisasian, dan mobiltas sumber daya yang diperlukan untuk mengatasi dampak bencana yang disebut sebagai fase yang unik (Kelly dalam Kusumasari, 2014:20).

Ketika terjadinya bencana, hal yang diutamakan adalah keselamatan masyarakat yang terkena dampak bencana, penanganan bencana yang responsif akan memberikan rasa aman bagi masyarakat yang terkena bencana (Frinaldi, 2019).

Khan dalam Alhadi (2014) menyatakan bahwa pengertian dari manajemen bencana berfungsi untuk mencari jalan keluar atas persoalan bencana yang sudah menjadi masalah orang banyak, oleh sebab itu, manajemen bencana berfungsi agar akibat buruk yang terjadi akibat bencana dapat direduksi.

Sedangkan menurut Sadisun dalam Alhadi (2014) menjelaskan bahwa manajemen bencana diartikan sebagai 
aktivitas yang teratur, hidup dan berkepanjangan, yang dilaksanakan ketika prabencana hingga pasca bencana. Maka dari itu, manajemen bencana merupakan perpaduan dari semua tahapan bencana mulai dari pra bencana, saat bencana, dan pasca bencana.

Jadi, berdasarkan pendapat diatas, penulis dapat menyimpulkan bahwa manajemen bencana dapat disebut sebagai segala aktivitas yang berkaitan dengan kebencanaan dan dilakukan melalui berbagai proses seperti pencegahan, mitigasi bencana dan kesiapsiagaan bencana, tanggap darurat serta pemulihan yang berguna untuk mengatasi ancaman yang diakibatkan oleh bencana yang terjadi.

\section{Tujuan Manajemen Bencana}

Secara sederhana, tujuan dari manajemen bencana yaitu untuk meminimalisir jatuhnya korban jiwa dan harta benda yang disebabkan oleh bencana.

Berbagai pihak masih banyak kurang menyadari akan pentingnya untuk mengelola bencana. Alasan utamanya karena bencana belum tau kapan datangnya untuk itu, kegiatan manajemen bencana sangat dibutuhkan apabila suatu saat bencana terjadi. Djohanputro dalam Alhadi (2014) menyebutkan tujuan dari manajemen bencana, yaitu:

1) Untuk meminimalisir terjadinya kerugian baik kerugian yang terjadi pada individu maupun masyarakat, serta bangsa dan negara. Tindakan yang dilakukan tergolong ke dalam tindakan sebelum terjadinya bencana (prabencana). Maka dari itu, tindakan ini dapat dikatakan efektif apabila dilakukan ketika prabencana.

2) Untuk meminimalisir kerugian yang terjadi pada masing-masing individu maupun masyarakat yang berupa kerugian ekonomi, fisik dan lain sebagainya. Hal ini bertujuan agar kn dapat diminimalisir dan akan terlaksana dengan efektif apabila sudah dilakukan ketika bencana itu sudah terjadi.
3) Untuk mengurangi penderitaaan yang dialami oleh individu dan masyarakat serta negara yang terkena dampak bencana. Dalam melaksanakan suatu tindakan pengentasan, tujuan utama nya adalah untuk meringankan beban masing-masing individu dan masyarakat yang terkena dampak bencana agar bisa bertahan hidup.

4) Agar kondisi dan musibah yang dialami oleh individu dan masyarakat dapat diperbaiki perlahan-lahan, tindakan ini dilakukan melalui perbaikan infrastruktur, sarana dan prasarana, penyediaan air bersih dan sebagainya.

5) Membantu agar mepercepat perbaikan keadaan individu dan masyarakat menuju kondisi normal seperti sebelumnya, dan mengejar ketertinggalan dengan individu maupun masyarakat yang tidak merasakan dampak dari bencana yang terjadi.

\section{Mitigasi}

Berdasarkan Undang-Undang Nomor 24 Tahun 2007 tentang penanggulangan bencana pasal 1 ayat 9 menjelaskan bahwa mitigasi adalah semua kegiatan yang dilakukan dalam mengurangi resiko akibat terjadinya bencana, yang dilakukan melalui pembangunan fisik ataupun penyadaran dan peningkatan kemampuan dalam menanggapi berbagai ancaman yang disebabkan oleh bencana yang terjadi.

Menurut King mitigasi merupakan suatu tindakan yang dilakukan sebelum bencana itu terjadi yang memiliki tujuan agar dapat meminimalisir maupun menghilangkan dampak yang diakibatkan oleh bencana terhadap individu, masyarakat dan lingkungan sekitarnya. Pencegahan atau pengurangan risiko merupakan ungkapan yang selalu berkaitan dengan mitigasi, mitigasi juga dianggap sebagai landasan manajemen bencana. Apabila tindakan kesiapsiagaan, respons terhadap bencana dan kegiatan pemulihan dilaksanakan dengan tujuan untuk memberikan tanggapan terhadap bencana yang terjadi. Langkah-langkah yang dilakukan dalam 
kegiatan mitigasi bencana berusaha untuk meminimalisir risiko yang terjadi akibat bencana yang dilakukan sebelum bencana terjadi. (Kusumasari, 2014:22).

Sudibyakto (2011:1) mengungkapkan bahwa bencana merupakan suatu rangkaian peristiwa yang mengakibatkan penderitaan bagi orang yang mengalaminya, kerugian harta benda, kerusakan lingkungan, sarana dan prasarana serta dapat mengakibatkan terganggunya kehidupan masyarakat dan lingkungannya.

Secara sederhana tujuan dari mitigasi bencana merupakan kegiatan yang dilakukan untuk mengurangi adanya korban jiwa dan harta benda akibat terjadinya bencana. Berbagai pihak masih banyak yang belum mengerti bahwa perlunya pengelolaan bencana yang benar, karena bencana belum tahu kapan datangnya, maka kita harus selalu mempersiapkan diri ketika dalam menghadapi berbagai ancaman yang terjadi. Dari tujuan tersebutlah mitigasi bencana diperlukan agar masing-masing individu dan masyarakat dapat berusaha melakukan kegiatan pencegahan agar dapat mengurangi ancaman yang disebabkan oleh bencana yang dialami.

Jadi dapat penulis simpulkan bahwa kegiatan mitigasi bencana merupakan serangkaian upaya yang dilakukan dari prabencana dan bertujuan untuk mengurangi ancaman serta dampak buruk dari bencana yang tidak diketahui kapan datangnya.

\section{METODE PENELITIAN}

Dalam penelitian ini, pendekatan yang digunakan adalah pendekatan kualitatif, dengan menggunakan metode deskriptif, penelitian ini berlokasi di Kelurahan Olo Kecamatan Padang Barat yang berada di sekitar kawasan Pantai Padang. Pemberi informasi (informan) dipilih menggunakan teknik purposive sampling. Data yang digunakan dalam penelitian ini yaitu data primer dan data sekunder. Teknik pengumpulan data dilakukan dengan cara observation/pengamatan, interview dan documentation study. Uji keabsahan data menggunakan teknik triangulasi sumber. Sedangkan teknik analisis data yang digunakan yaitu reduksi data, pengumpulan dan penyediaan data serta penarikan kesimpulan.

\section{HASIL DAN PEMBAHASAN}

Latar belakang terbentuknya organisasi kelompok sosial masyarakat atau yang disebut juga dengan Kelompok Siaga Bencana di Kota Padang ini dilandasi oleh tingkat potensi bencana yang dimiliki oleh Kota Padang sangat tinggi dan dapat mengancam kehidupan masyarakat. Kelompok Siaga Bencana Kelurahan Olo dibentuk oleh Pemerintah daerah dalam hal ini BPBD Kota Padang untuk membantu melakukan kegiatan mengenai kebencanaan.

Peran Kelompok Siaga Bencana yaitu yang pertama, memberikan informasi dan sosialisasi kepada masyarakat mengenai bencana seperti gempa bumi dan tsunami, Disisi lain, Kelompok Siaga Bencana melakukan upaya mitigasi bencana, pada saat prabencana, pasca bencana serta mendata dan melaporkan bencana yang terjadi di sekitar lingkungan tempat tinggalnya kepada Pemerintah Daerah dalam hal ini yaitu BPBD.

Pelaksanaan peran Kelompok Siaga Bencana di kelurahan Olo dapat diketahui dari segi penyampaian informasi yang dilakukan kepada masyarakat di Kelurahan Olo belum berjalan secara maksimal karena masih ada beberapa masyarakat yang belum mendapatkan. Selain itu sosialisasi yang dilakukan hanya kedaerah yang memang terdampak langsung terhadap ancaman bencana. Karena keterbatasan dana, kegiatan yang dilakukan kedaerah-daerah yang rawan tersebut tidak merata dilakukan.

Selain itu kegiatan sosialisasi yang dilakukan tidak rutin dijalankan dimana kegiatan kebencanaan dilakukan hanya memanfaatkan momen tertentu, seperti kegiatan yang berasal dari BPBD untuk mensosialisasikan Padang Kota Cerdas Bencana. Di lain hal pelatihan yang 
diterima oleh angota Kelompok Siaga

Bencana Kelurahan Olo masih kurang dimana mereka hanya mendapatkan pelatihan sekali dalam setahun dan tidak semua anggota Kelompok Siaga Bencana Kelurahan Olo mendapatkan pelatihan tersebut, karena hanya beberapa orang yang di ikut sertakan dalam pelatihan tersebut, otomatis untuk menunggu anggota lain mendapatkan pelatihan membutuhkan waktu yang cukup lama. Sedangkan kegiatan yang dilakukan oleh anggota Kelompok Siaga Bencana Kelurahan Olo sendiri tidak ada.

Jadi, dapat diketahui bahwa kemampuan anggota Kelompok Siaga Bencana dalam melakukan sosialiasi pada dasarnya hanya difokuskan kepada masyarakat yang betempat tinggal di sekitar pesisir pantai, karena Namun ketika peneliti mensurvei kedaerah yang telah ditargetkan tersebut, peneliti mendapati bahwa masih ada masyarakat di daerah pesisir pantai tersebut yang belum tahu dengan keberadaan Kelompok Siaga Bencana, otomatis mereka belum mendapatkan sosialiasi dari anggota Kelompok Siaga Bencana tersebut. Jadi kemampuan anggota Kelompok Siaga Bencana dalam melakukan koordinasi dengan masyarakat disana bisa dikatakan masih kurang, dimana tugas dan fungsi dari anggota Kelompok Siaga Bencana tersebut kurang berjalan dengan baik. Dapat dikatakan kemampuan anggota Kelompok Siaga Bencana Kelurahan Olo dalam melaksanakan sosialiasi sesuai dengan perannya belum maksimal.

Berkaitan dengan efektivitas pelaksanaan peran Kelompok Siaga Bencana Kelurahan Olo dalam upaya mitigasi bencana gempa bumi dan tsunami di kawasan Pantai Padang, dapat diukur dengan menggunakan indikator efektivitas yang dikemukakan oleh Habe (2008) dalam Sujanto (2017:16:19) yaitu sebagai berikut: 1) Kemampuan, 2) Pegetahuan, 3) Motivasi.

\section{Kemampuan}

Kemampuan anggota Kelompok Siaga Bencana dalam melakukan sosialiasi hanya terfokus kepada masyarakat yang tempat tinggalnya berdekatan dengan pesisir pantai, karena pada dasarnya mereka memang memfokuskan kedaerah yang tingkat kerawanannya paling tinggi yaitu di daerah pesisir pantai. Namun ketika peneliti meneliti kedaerah yaang telah ditargetkan tersebut, peneliti mendapati bahwa masih ada masyarakat di daerah pesisir pantai tersebut yang belum tahu dengan keberadaan Kelompok Siaga Bencana, otomatis mereka belum mendapatkan sosialiasi dari anggota Kelompok Siaga Bencana tersebut. Jadi kemampuan anggota Kelompok Siaga Bencana dalam melaksanakan perannya kurang berjalan dengan baik. Dapat dikatakan kemampuan anggota Kelompok Siaga Bencana Kelurahan Olo dalam menyampaikan informasi dan memberikan sosialiasi kepada masyarakat sesuai dengan tugas dan fungsinya belum maksimal karena masih kurangnya koordinasi yang dilakukan antara anggota Kelompok Siaga Bencana Kelurahan Olo dengan masyarakat sekitar.

\section{Pengetahuan}

Dalam penelitian ini pengetahuan yang di terima oleh anggota Kelompok Siaga Bencana Kelurahan Olo dalam hal pelatihan kebencanaan seperti kegiatan mitigasi bencana belum cukup, karena mereka hanya mendapatkan pelatihan sekali setahun dari BPBD Kota Padang. Dapat dikatakan pelatihan yang diterima oleh anggota Kelompok Siaga Bencana Kelurahan Olo ini masih kurang merata karena dalam setiap tahunnya hanya beberapa orang yang diikutsertakan dalam setiap kegiatan pelatihan bencana, jadi mereka selalu bergiliran menerima pelatihan dari BPBD Kota Padang. Pelatihan yang diterima setiap tahunnya kurang lebih sama materinya yaitu tentang kebencanaan oleh karena itu 
dalam hal segi kebencanaan mereka sudah paham. Tingkat pengetahuan yang dimiliki oleh anggota Kelompok Siaga Bencana Kelurahan Olo pada umumnya sudah merata dalam hal kebencanaan tergantung bagaimana mereka mendapatkan dan memahami pelatihan yang diberikan oleh BPBD.

\section{Motivasi}

Dalam segi motivasi yang dimiliki oleh anggota Kelompok Siaga Bencana Kelurahan Olo kurang lebih sama karena mereka bergabung dengan Kelompok Siaga Bencana tersebut karena rasa peduli terhadap masyarakat dan lingkungannya atau dorongan ingin membantu sesama. Seperti yang diketahui bahwa Kota Padang adalah daerah yang rawan bencana kemudian Kelurahan Olo yang berada disekitar kawasan Pantai Padang adalah salah satu wilayah di Kota Padang yang memiliki tingkat kerawanan bencana gempa dan tsunami sangat tinggi karena berdekatan dengan pesisir pantai. Hal tersebutlah yang menjadikan mereka mau bergabung dengan Kelompok Siaga Bencana Kelurahan Olo. Dimana rasa keterpanggilan untuk membantu sesama, mereka tidak memikirkan apa yang akan mereka peroleh atau apa yang mereka dapatkan dari ikut bergabung dengan Kelompok Siaga Bencana tapi mereka ingin memberikan apa yang bisa mereka berikan kepada masyarakat di Kelurahan Olo. Apakah itu dari segi ilmu pengetahuan tentang kebencanaan atau dari segi informasi maupun dari bantuan tenaga sendiri.

\section{PENUTUP}

Berdasarkan penelitian yang sudah dilaksanakan sebelumnya, maka penulis telah mendapatkan hasil dan pembahasan mengenai hasil penelitian tersebut, maka dapat disimpulkan bahwa:

1. Efektivitas pelaksanaan peran Kelompok Siaga Bencana Kelurahan
Olo setelah diukur dengan indikator efektivitas menurut Habe (2008) ternyata cukup efektif namun kurang optimal. Hal ini disebabkan karena peran Kelompok Siaga Bencana Olo sebagai relawan sosial dalam kegiatan mitigasi bencana belum terealisasi ke seluruh lapisan masyarakat. Artinya disini, masih ada sebagian masyarakat yang belum mendapatkan sosialisasi terkait upaya mitigasi bencana gempa bumi dan tsunami dari Kelompok Siaga Bencana Kelurahan Olo. Jika dilihat dari segi kemampuan, anggota Kelompok Siaga Bencana Kelurahan Olo masih minim dalam hal pengetahuan tentang kebencanaan karena mereka hanya diberikan pelatihan sekali dalam setahun oleh BPBD dan hanya beberapa anggota Kelompok Siaga Bencana Kelurahan Olo yang bisa mengikutinya. Oleh sebab itu, penyampaian informasi dan kegiatan sosialisasi terkait mitigasi bencana dilakukan hanya sebatas kemampuan dan pelatihan yang telah mereka terima. Jadi, peran Kelompok Siaga Bencana Kelurahan Olo dari segi kemampuan belum berjalan dengan baik.

2. Dilihat dari segi pengetahuan yang dimiliki oleh anggota Kelompok Siaga Bencana Kelurahan Olo mengenai kegiatan kebencanaan sudah cukup baik, hal ini disebabkan karena pada dasarnya anggota Kelompok Siaga Bencana Kelurahan Olo disamping sudah mendapatkan pelatihan dari BPBD Kota Padang, anggota Kelompok Siaga Bencana Kelurahan Olo sudah memiliki pengetahuan sedikit banyaknya dari berbagai media seperti internet, handphone, dan lain sebagainya terkait mitigasi bencana gempa bumi dan tsunami ini. Namun, dari segi pelatihan yang didapatkan dari BPBD Kota Padang masih sangat minim dan hanya dilakukan setahun sekali. Oleh sebab itu, agar pelatihan merata didapatkan oleh semua anggota 
Kelompok Siaga Bencana Kelurahan Olo haru menunggu waktu yang cukup lama. Jadi, dapat disimpulkan bahwa dari segi pengetahuan yang dimiliki oleh anggota Kelompok Siaga Bencana Kelurahan Olo sudah cukup baik, namun belum maksimal, karena masih minimnya pelatihan yang diberikan oleh BPBD Kota Padang kepada Kelompok Siaga Bencana Kelurahan Olo.

3. Jika dilihat dari segi motivasi yang dimiliki oleh anggota Kelompok Siaga Bencana Kelurahan Olo mengenai kegiatan kebencanaan yaitu mereka memiliki motivasi yang sama untuk ikut bergabung menjadi relawan sosial yang secara sukarela membantu Pemerintah Kota Padang untuk ikut dalam kegiatan upaya mitigasi bencana terutama bencana gempa bumi dan tsunami, agar masyarakat dapat mengambil tindakan yang tepat dan selalu siap siaga jika sewaktu-waktu terjadinya bencana.

Berdasarkan hasil yang didapatkan dari penelitian yang telah dilakukan, peneliti akan memberikan beberapa saran, antara lain:

1. Berhubungan dengan penyampaian informasi dan kegiatan sosialisasi yang dilakukan oleh Kelompok Siaga Bencana Kelurahan Olo hendaknya dilakukan merata ke seluruh masyarakat, sehingga masyarakat samasama mengetahui akan pentingnya upaya mitigasi bencana gempa bumi dan tsunami ini terlebih lagi lokasi Kelurahan Olo yang berada dekat dengan pesisir pantai yang menyebabkan Kelurahan Olo sangat rentan terhadap ancaman yang disebabkan oleh bahaya gempa bumi dan tsunami.

2. Terkait dengan pelatihan yang dilaksanakan, diharapkan Kelompok Siaga Bencana Kelurahan Olo tidak hanya mengandalkan kgiatan pendidikan dan pelatihan yang berasal dari Pemerintah Daerah saja, kegiatan pelatihan sebaiknya tetap dijalankan tidak hanya kegiatan yang berasal dari Pemerintah Daerah saja.

\section{DAFTAR KEPUSTAKAAN}

Alhadi, Z. (2014). Kesiapan Jalur Dan Lokasi Evakuasi Publik Menghadapi Resiko Bencana Gempa Dan Tsunami Di Kota Padang (Studi Manajemen Bencana). Humanus Vol. XIII No.1 Th. 2014.

Gusfi, Putri Septia. (2018). The effectiveness of external organization coomunication on regional disaster management agencyat Padang City in implementing the tsunami early warning system. Padang. Fakultas Ilmu Sosial. Universitas Negeri Padang. MATEC Web Conf Vol. 229 No. 1.

http://www.bmkg.go.id, 19 Desember 2012).

Humaedi, M Alie., Hisyam, M. Seftiani, Sari., Rambeth, J Viktor. (2013). Efektivitas Peran Kepemimpinan Lokal dalam Upaya Pengurangan Resiko Bencana di Indonesia: Prosiding Geoteknologi LIPI.

Kusumasari, Bevaola. (2014). Manajemen Bencana dan Kapabilitas Pemerintah Lokal. Yogyakarta: Penerbit Gava Media.

Mukhtar. (2013). Metode Praktis Penelitian Deskriptif Kualitatif. Jakarta Selatan: Referensi (GP Press Group).

SK Lurah Olo Kecamatan Padang Barat.

Sriwahyuni, Aldri Frinaldi. (2019). Budaya Kerja Sadar Wisata Yang Responsif Bagi Keselanatan Pengunjung (Studi Kolaborasi Pemerintah Kota Padang Dengan Padang Baywatch Di Kawasan Pantai Padang. Padang. Fakultas Ilmu Sosial. Universitas Negeri Padang. 
Chece Syahyanti, Aldri FrinaldilEfektivitas Pelaksanaan Peran Kelompok Siaga Bencana Kelurahan Olo dalam Upaya Mitigasi Bencana Gempa Bumi dan Tsunami di Kawasan Pantai Padang

Steers, Richard M. (1985). Efektivitas organisasi. Jakarta: Erlangga.

Undang-Undang Nomor 24 Tahun 2007 tentang Penanggulangan Bencana. 